\title{
A Novel Use of 3-Methyl-2-Benzothiazolinone Hydrazone Hydrochloride Monohydrate for Kinetic Spectrophotometric Determination of Captopril in Pharmaceutical Formulations
}

\author{
Mouhammed Khateeb ${ }^{1^{*}}$, Basheer Elias ${ }^{2}$, Shahama Adi ${ }^{3}$ \\ ${ }^{1}$ Department of Basic Sciences, Faculty of Mechanical and Electrical Engineering, \\ University of Al-Baath, Homs, Syria \\ ${ }^{2,3}$ Department of Chemistry, Faculty of Sciences, University of Al- Baath Homs, Syria \\ *E-mail: drkhateeb2010@gmail.com, mkhateeb74@hotmail.com
}

\begin{abstract}
Keywords: Captopril, 3-methyl-2-benzothiazolinone hydrazone hydrochloride monohydrate
\end{abstract} (MBTH), Kinetic spectrophotometry, pharmaceutical formulations.

\begin{abstract}
A new, simple and sensitive kinetic spectrophotometric method has been proposed for the determination of captopril (CPT) in pharmaceutical formulations. The method is based on oxidation of 3-methyl-2-benzothiazolinone hydrazone hydrochloride monohydrate (MBTH) by ferric chloride followed by its coupling with the drug to form green- yellow coloured product with absorbance maximum at $395 \mathrm{~nm}$. The concentration of CPT was calculated using the calibration equation for the rate data and fixed time methods. The linearity range was found to be $0.5-$ $22.5 \mu \mathrm{g} \mathrm{mL}^{-1}$ for each method. The correlation coefficients were 0.9994 and 0.9971 for rate data and fixed time methods respectively. The proposed methods were applied successfully for the determination of CPT in pharmaceutical formulations. Statistical comparison of the results shows that there is no significant difference between the proposed and official methods.
\end{abstract}

\section{Introduction}

Captopril (CPT), 1-(3-mercapto-2-D-methyl-1-oxoproppyl)-1-proline (S,S) (Fig. 1), is an angiotensin-converting enzyme (ACE) inhibitor, the enzyme responsible for the conversion of angiotensin I (ATI) to angiotensin II (ATII). ATII regulates blood pressure and is a key component of the renin-angiotensin-aldosterone system (RAAS) [1]. Captopril has been used for the treatment of hypertension, congestive heart failure, and left ventricular dysfunction after myocardial infarction. About $60-75 \%$ of a dose of CPT is absorbed from the gastro-intestinal tract and peak plasma concentration is achieved in about an hour. About $30 \%$ of the drug is bound to plasma protein [2-3].

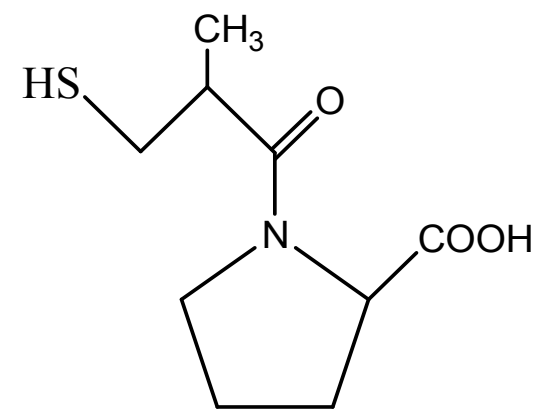

Figure 1. Chemical structure of Captopril.

In order to assure the quality of CPT containing pharmaceutical formulations, several analytical methods have been reported for its determination, including spectrophotometric [4-9], kinetic spectrophotometric methods [10-13], high performance liquid chromatography (HPLC) [1416], polarography [17], stripping voltammetry [18-19], fluorimetry [20], atomic absorption spectrophotometry [21], flow injection analysis [22-25], and potentiometry [26]. 
Kinetic spectrophotometric methods are becoming of great interest in pharmaceutical analysis [27]. Some specific advantages in the application of kinetic methods can be expected such as: selectivity due to the measurement of the evolution of the absorbance with the time of the reaction instead of the measure of a concrete absorbance value, sufficient accuracy and requires relatively simple and inexpensive instrumentation [28].

The present work describes the development of a simple and sensitive kinetic spectrophotometric method for the determination of CPT in pharmaceutical formulations. The method is based on the oxidative coupling reaction of 3-methyl-2-benzothiazolinone hydrazone hydrochloride monohydrate (MBTH) with $\mathrm{CPT}$ in the presence of ferric chloride to form greenyellow coloured chromogen with absorption maximum at $395 \mathrm{~nm}$. Optimum conditions were established and the method was validated for linearity, sensitivity, accuracy and precision.

\section{Experimental}

\subsection{Apparatus}

An Optizen UV2120 UV-VIS spectrophotometer with $1 \mathrm{~cm}$ quartz cells was used for all absorbance measurements under the following operating conditions: scan speed medium (400 $\mathrm{nm} / \mathrm{min}$ ), scan range $200-1100 \mathrm{~nm}$ and slit width $1 \mathrm{~nm}$. Spectra were automatically obtained by Optizen system software. $\mathrm{pH}$ measurements were made with ORION 250A (USA) with combined glass $\mathrm{pH}$ electrode.

\subsection{Reagent and Chemicals}

All chemicals were of analytical grade. Double distilled water was used throughout all experiments. Captopril (CPT), $\left(\mathrm{C}_{9} \mathrm{H}_{15} \mathrm{NO}_{3} \mathrm{~S}\right), 217.28 \mathrm{~g} \cdot \mathrm{mol}^{-1}$ was obtained from Kunshan chemical and pharmaceutical Co., Ltd, Its purity was found to be $99.5 \%$ according to the compendial method. 3-methyl-2-benzothiazolinone hydrazone hydrochloride monohydrate (MBTH) was obtained from Fluka and ferric chloride was from Merck.

\subsection{Formulations}

Captomed tablets supplied by Medico Company (Homs, Syria), each tablet was labeled to contain 25 or $50 \mathrm{mg}$ Captopril and Capoten tablets supplied by Unipharma (Damascus, Syria), each tablet was labeled to contain 25 or $50 \mathrm{mg}$ Captopril.

\subsection{Solutions}

Standard stock solution of CPT $\left(100 \mu \mathrm{g} \mathrm{mL}^{-1}\right)$ was prepared by dissolving $10.05 \mathrm{mg}$ of CPT in $100 \mathrm{~mL}$ of double distilled water. $1.0 \times 10^{-2} \mathrm{M}$ MBTH solution was prepared with double distilled water and $0.5 \% \mathrm{FeCl}_{3}$ solution was prepared with hydrochloric acid $(0.1 \mathrm{M})$ medium. Freshly prepared solutions were always used.

\subsection{General procedures}

\subsubsection{Rate data method}

Aliquots $0.5-22.5 \mu \mathrm{g} \mathrm{mL}^{-1}$ of CPT stock solution $\left(0.05-2.25 \mathrm{~mL}, 100 \mu \mathrm{g} \mathrm{mL}^{-1}\right)$ were pipette into a series of $10 \mathrm{~mL}$ volumetric flasks. To each flask, $1.0 \mathrm{~mL}$ of $0.5 \% \mathrm{FeCl}_{3}$ solution was added, followed by $1.0 \mathrm{~mL}$ of $1 \times 10^{-2} \mathrm{M}$ MBTH and then diluted to the volume with double distilled water at $25^{\circ} \mathrm{C}$. Flask contents were shaken and immediately transferred to the spectrophotometric cell and the increase in absorbance at $395 \mathrm{~nm}$ of each flask was recorded as a function of time over 4-16 min against reagent blank treated similarly. The rate data of the reaction $(v)$ at different concentrations was obtained from the slope of the absorbance time curves. The calibration graphs were constructed by plotting the logarithm of the rate data of the reaction $(\log v)$ versus logarithm of molar concentration of CPT $(\log \mathrm{C})$. 


\subsubsection{Fixed time method}

Aliquots $0.5-22.5 \mu \mathrm{g} \mathrm{mL}^{-1}$ of CPT stock solution $\left(0.05-2.25 \mathrm{~mL}, 100 \mu \mathrm{g} \mathrm{mL} \mathrm{m}^{-1}\right)$ were pipette into a series of $10 \mathrm{~mL}$ volumetric flasks. To each flask, $1.0 \mathrm{~mL}$ of $0.5 \% \mathrm{FeCl}_{3}$ solution was added, followed by $1.0 \mathrm{~mL}$ of $1 \times 10^{-2} \mathrm{M}$ MBTH and then diluted to the volume with double distilled water at $25{ }^{\circ} \mathrm{C}$. Flask contents were shaken and immediately transferred to the spectrophotometric cell. Absorbance of each sample solution was recorded at $395 \mathrm{~nm}$ against reagent blank treated similarly. The calibration curves were constructed by plotting the absorbance measured after a fixed time of (8 min) against the final concentration of the CPT.

\subsection{Procedure for formulations}

Ten tablets of each formulation were weighed and finely powdered. An accurately weighed amount of the powder equivalent to $10 \mathrm{mg}$ of CPT was dissolved in $20 \mathrm{~mL}$ methanol, mixed well for $10 \mathrm{~min}$, and filtered through Whatman filter paper (No. 1). The methanol was evaporated to dryness. The remaining portion of solution was dissolved in a $100 \mathrm{~mL}$ volumetric flask to the volume with double distilled water to achieve a concentration of $100 \mu \mathrm{g} \mathrm{mL}^{-1}$ approximately. The general procedures were then followed in the concentration ranges mentioned above.

\section{Results and Discussion}

\subsection{Absorption spectra}

The method involves the reaction of CPT with MBTH in the presence of an oxidant iron(III) chloride to give green- yellow colored products with maximum absorption at $395 \mathrm{~nm}$ (Fig. 2).

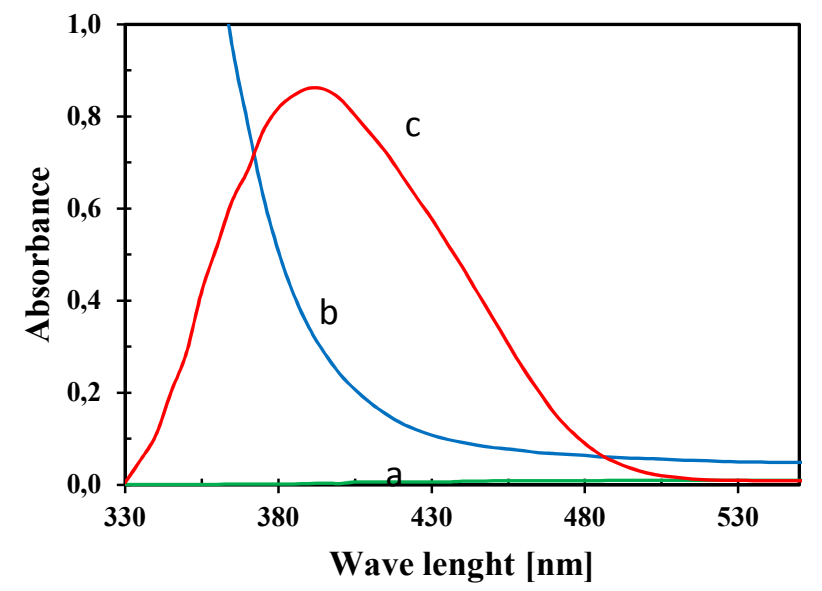

Figure 2. Absorption spectra of (a) $10 \mu \mathrm{g} \mathrm{mL}^{-1} \mathrm{CPT}$ against water, (b) reagent blank solution against water and (c) the reaction product CPT-MBTH- $\mathrm{FeCl}_{3} \cdot \mathrm{C}_{\mathrm{CPT}}=10 \mu \mathrm{g} \mathrm{mL} \mathrm{m}^{-1}+1 \mathrm{~mL}$ of $0.5 \%$ $\mathrm{FeCl}_{3}+1 \mathrm{~mL}$ of $10^{-2} \mathrm{M} \mathrm{MBTH}$.

Under reaction conditions, MBTH (I), on oxidation with $\mathrm{Fe}^{3+}$ ions, loses two electrons and one proton forming an electrophilic intermediate (II), which is the active coupling species [29]. The electron density in these drugs studied is highest at the two and eight positions, which permits electrophilic substitution by reagents [30] (Scheme 1). 
<smiles>Cn1c(=NN)sc2ccccc21</smiles>

II<smiles>CC(CS)C(=O)N1CCCC1C(=O)O</smiles>

Scheme 1. The proposed pathway of the reaction between CPT and MBTH.

\subsection{Optimization of reaction conditions}

The optimum conditions for the development of methods were established by varying the parameters one at a time and keeping the others fixed and observing the effect produced on the absorbance of the colored oxidative coupling products.

The effect of various parameters such as volume of oxidant, volume of MBTH reagent, addition of buffer solutions and order of addition of reagents on color development and solvent for final dilution on the intensity were studied and the optimum conditions were established. A volume of $1.0 \mathrm{~mL}$ of $1 \times 10^{-2} \mathrm{M} \mathrm{MBTH}$ and $1.0 \mathrm{~mL}$ of $0.5 \% \mathrm{FeCl}_{3}$ were found to be optimal for maximum color development, since the absorbance was found to be maxima at the mentioned volumes (Fig. 3).
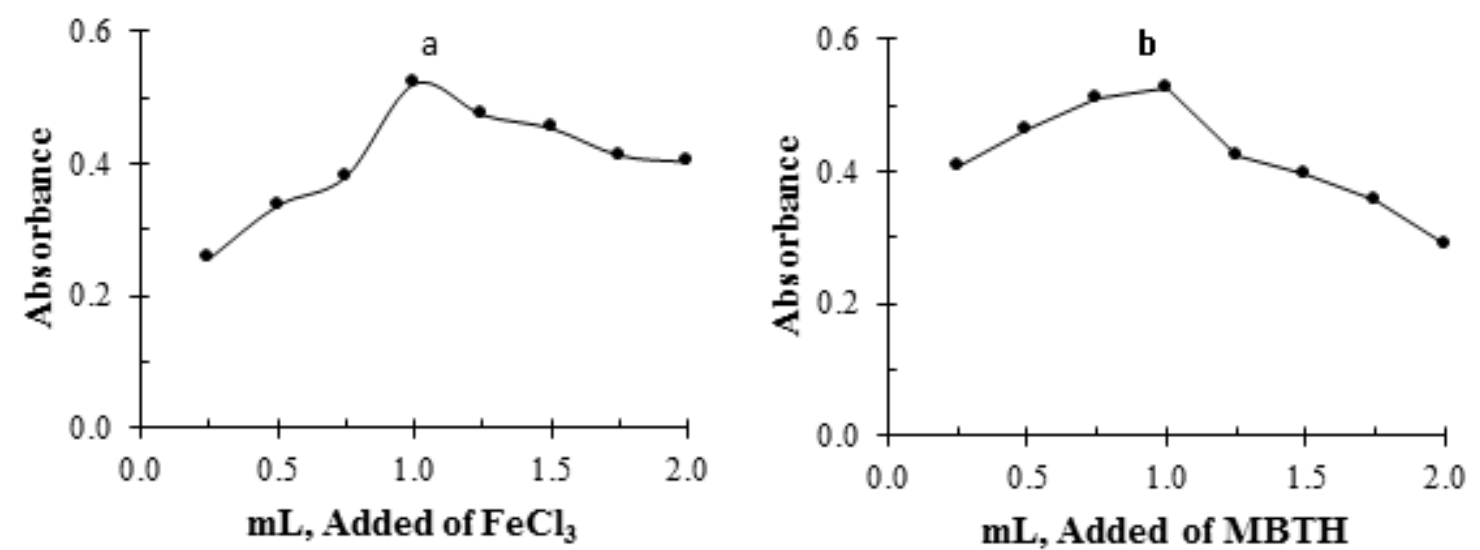

Figure 3. (a) Effect of concentration of $\mathrm{FeCl}_{3}$ in the presence of $1.0 \mathrm{~mL}$ of $10^{-2} \mathrm{M} \mathrm{MBTH}$,

(b) Effect of concentration of MBTH in the presence of $1.0 \mathrm{~mL}$ of $0.5 \% \mathrm{FeCl}_{3}$ on the formation of

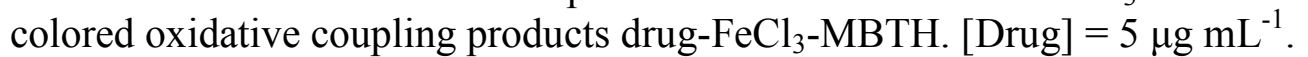

Among the various oxidants $\mathrm{NaIO}_{4}, \mathrm{~K}_{2} \mathrm{Cr}_{2} \mathrm{O}_{7}, \mathrm{Ce}\left(\mathrm{SO}_{4}\right)_{2}, \mathrm{FeCl}_{3}$ and $\mathrm{KIO}_{4}$ were examined in combination with MBTH for oxidative coupling reaction. Ce (IV) and Fe (III) were responded for color development with MBTH. But MBTH-Fe (III) was found to be the best by virtue of absorbance values and stability considerations. Other water miscible solvents like methanol, ethanol and acetonitrile were found to provide no additional advantage, so distilled water is selected as a solvent for final dilution of the colored species. Addition of $\mathrm{KCl}-\mathrm{HCl}$, britton and acetate buffer solutions affected negativity on the formation of colored oxidative coupling product. Addition of drug, $\mathrm{FeCl}_{3}$ and $\mathrm{MBTH}$ in that order gave maximum absorbance. 


\subsection{Quantitation methods}

Because the intensity of the color increased at $395 \mathrm{~nm}$ with time (Fig. 4), this was used as the basis for a useful kinetic method for the determination of CPT. The rate data, rate constant, fixed absorbance and fixed time methods [31,32] were carried out and the most suitable analytical methods were chosen regarding the applicability, sensitivity, the values of the intercept and correlation coefficient (r).

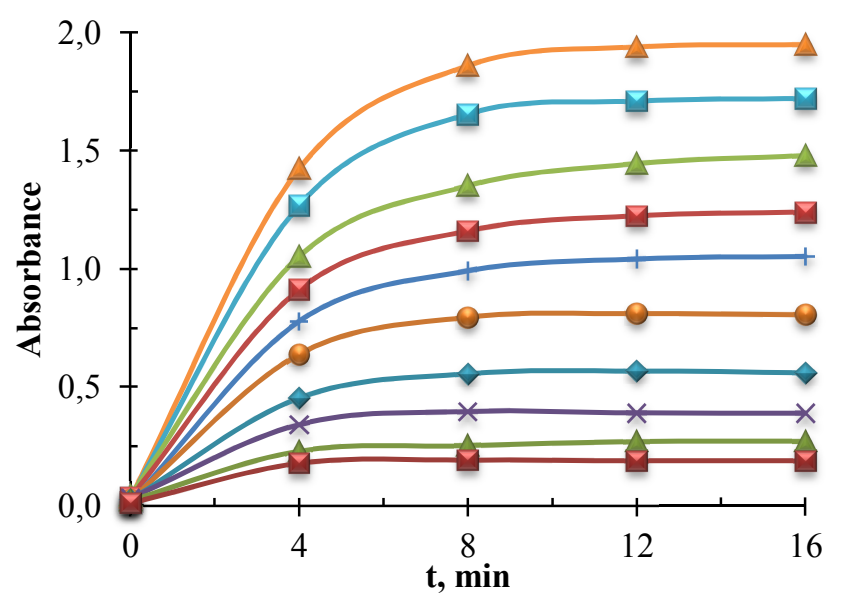

$\triangle 22.5 \mu \mathrm{g} / \mathrm{mL}$

$\rightarrow-20.0 \mu \mathrm{g} / \mathrm{mL}$

$\triangle 15.0 \mu \mathrm{g} / \mathrm{mL}$

$\rightarrow-12.5 \mu \mathrm{g} / \mathrm{mL}$

$+10.0 \mu \mathrm{g} / \mathrm{mL}$

$\multimap-7.5 \mu \mathrm{g} / \mathrm{mL}$

$\leadsto 5.0 \mu \mathrm{g} / \mathrm{mL}$

$\leftarrow 2.5 \mu \mathrm{g} / \mathrm{mL}$

$\triangle 1.0 \mu \mathrm{g} / \mathrm{mL}$

$\rightarrow-0.5 \mu \mathrm{g} / \mathrm{mL}$

Figure 4. Absorbance-time curve for reaction of CPT with $\mathrm{MBTH} ; \mathrm{C}_{\mathrm{CPT}}=0.5-22.5 \mu \mathrm{g} \mathrm{mL}^{-1}$.

\subsubsection{Rate data method}

The rate data of reaction would follow a pseudo order rate constant and obeyed the following rate equation:

$$
v=\frac{\Delta A}{\Delta t}=k^{\prime} . C^{n}
$$

Where $v$ is the reaction rate, $\mathrm{A}$ is the absorbance, $\Delta \mathrm{A}=\mathrm{A}_{\mathrm{t}_{1}}-\mathrm{A}_{\mathrm{t}_{1}}, \mathrm{t}$ is the measuring time, $\Delta \mathrm{t}=\mathrm{t}_{2}-\mathrm{t}_{1}$, $\mathrm{k}^{\prime}$ is the pseudo order rate constant, $\mathrm{C}$ is the concentration of the CPT mol L ${ }^{-1}$ and $\mathrm{n}$ is the order of the reaction. A calibration curve was constructed by plotting the logarithm of the rate of reaction $(\log v)$ versus $\log$ arithm of vitamin concentration $(\log C)$, which showed a linear relationship over the concentration range of $0.5-22.5 \mu \mathrm{g} \mathrm{mL}^{-1}$ (Fig. 5).

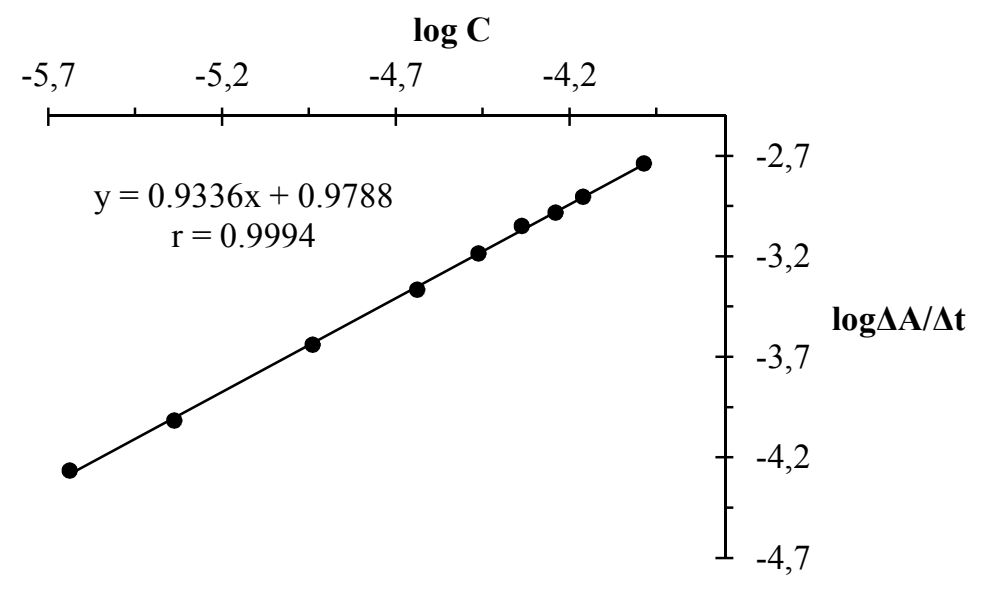

Figure 5. Calibration plot of logarithm rate of the reaction against logarithm molar concentration of CPT for rate method, $\left(t_{1}=4 ; t_{2}=8 \mathrm{~min}\right)$.

The logarithmic form of the above equation is written as follows:

$$
\begin{gathered}
\log v=\log \frac{\Delta A}{\Delta t}=\log \mathrm{k}^{\prime}+\mathrm{n} \log \mathrm{C} \\
\log v=\log \frac{\Delta A}{\Delta t}=0.9788+0.9336 \log [\mathrm{CPT}]
\end{gathered}
$$

Thus, $\mathrm{k}^{\prime}=9.52 \mathrm{~s}^{-1}$, and the reaction is the first order $(\mathrm{n}=0.9336 \approx 1)$ with respect to CPT concentration. 


\subsubsection{Rate constant method}

The logarithm of the absorbance of reaction versus time for each concentration of CPT which studied over the concentration range of 10.0-22.5 $\mu \mathrm{g} \mathrm{mL}^{-1}$ was calculated. Graphs of $\log$ absorbance versus time for CPT concentration in the range of $10.0-22.5 \mu \mathrm{g} \mathrm{mL}^{-1}\left(4.60 \times 10^{-5}-\right.$ $\left.1.04 \times 10^{-4} \mathrm{M}\right)$ were plotted and all appeared to be rectilinear. Pseudo order rate constant $\left(\mathrm{k}^{\prime}\right)$ corresponding to different CPT concentrations were calculated from the slopes multiplied by 2.303. Regression of $\mathrm{C}$ versus $\mathrm{k}^{\prime}$ gave the following equation:

$$
\mathrm{k}^{\prime}=-0.6619 \mathrm{C}-0.0004156 \quad(\mathrm{r}=0.8566)
$$

\subsubsection{Fixed absorbance method}

Reaction rate data were recorded for different CPT concentrations in the range $1-15 \mu \mathrm{g} \mathrm{mL} \mathrm{L}^{-1}$ $\left(4.6 \times 10^{-6}-6.9 \times 10^{-5} \mathrm{M}\right)$. A preselected value of the absorbance 0.2 was fixed and the time was measured in the seconds. The reciprocal of time $(1 / \mathrm{t})$ versus the initial concentration of CPT was plotted (Fig. 6) and the following equation of calibration graph was obtained.

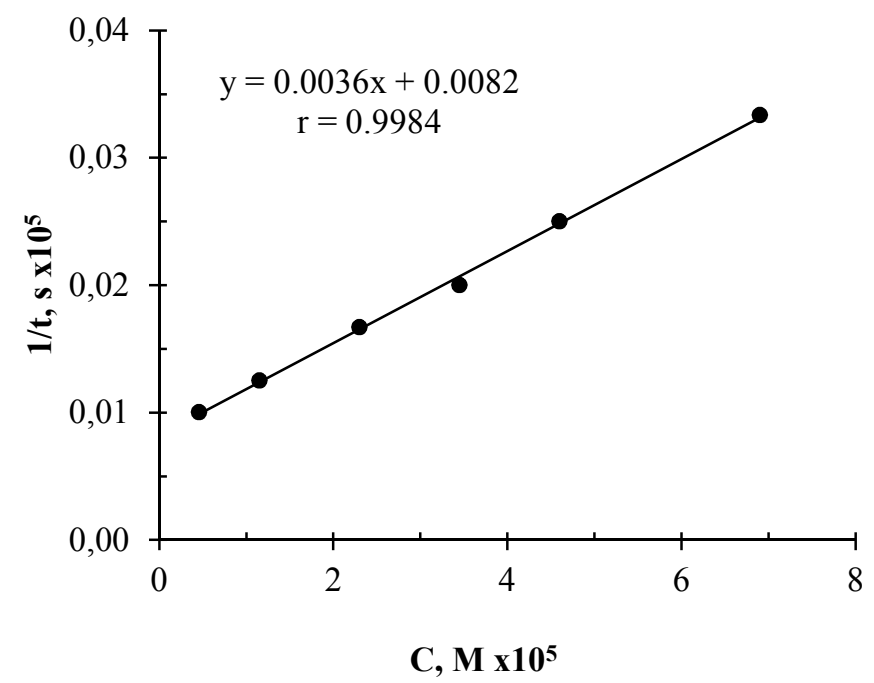

Figure 6. Calibration plot of CPT for fixed absorbance method.

\subsubsection{Fixed time method}

At preselected fixed time, the absorbance of green- yellow colored solution containing varying amounts of CPT was measured at $25{ }^{\circ} \mathrm{C}$ and $395 \mathrm{~nm}$. Calibration graphs were constructed by plotting the absorbance against the initial concentration of CPT at fixed time 4, 8, 12 and 16 min. The regression equations, correlation coefficients and linear ranges are given in Table 1 . It is clear that, the slope increases with time and the most acceptable value of $r$ was obtained for a fixed time of $8 \mathrm{~min}$. Therefore, the fixed time of $8 \mathrm{~min}$ was utilized for the assay of CPT concentration.

As a result, the most acceptable values of the correlation coefficient and linear range were obtained for the rate data $\left(t_{1}=4 ; t_{2}=8 \mathrm{~min}\right)$ and fixed time $(8 \mathrm{~min})$ methods. Thus, they were used for the determination of CPT in pharmaceutical formulations.

Table 1. Regression equations for CPT at fixed time and $25^{\circ} \mathrm{C}$.

\begin{tabular}{|c|l|c|c|}
\hline Time $(\mathrm{min})$ & Regression equation & Correlation coefficient & Linear range $\left(\mu \mathrm{g} \mathrm{mL}^{-1}\right)$ \\
\hline 4 & $\mathrm{~A}=0.0553 \mathrm{C}+0.2047$ & 0.9937 & $0.5-22.5$ \\
\hline $\mathbf{8}$ & $\mathbf{A}=\mathbf{0 . 0 7 5 2 C}+\mathbf{0 . 1 9 5 2}$ & $\mathbf{0 . 9 9 7 1}$ & $\mathbf{0 . 5 - 2 2 . 5}$ \\
\hline 12 & $\mathrm{~A}=0.0788 \mathrm{C}+0.1980$ & 0.9948 & $0.5-22.5$ \\
\hline 16 & $\mathrm{~A}=0.0798 \mathrm{C}+0.1960$ & 0.9931 & $0.5-22.5$ \\
\hline
\end{tabular}

A: absorbance; $\mathrm{C}$ : concentration. 


\subsection{Analytical method validation}

\subsubsection{Calibration graph}

After optimizing the reaction conditions, the linearity range was found to be $0.5-22.5 \mu \mathrm{g} \mathrm{mL} \mathrm{L}^{-1}$ for each method. Analysis of the data gave the following regression equations shown in Table 2 . Regression analysis indicates linear relationships with negligible intercepts. For fixed time (8min) method Sandell's sensitivity and molar absorptivity were calculated. Values of some analytical characteristics for the rate data $\left(t_{1}=4 ; t_{2}=8 \mathrm{~min}\right)$, and fixed time $(8 \mathrm{~min})$ methods are shown in Table 2.

Table 2. Analytical characteristics of the rate data and fixed time methods.

\begin{tabular}{|c|c|c|}
\hline Parameters & $\begin{array}{c}\text { Rate data } \\
\left(t_{1}=4 ; t_{2}=8 \mathrm{~min}\right)\end{array}$ & $\begin{array}{l}\text { Fixed time } \\
(8 \mathrm{~min})\end{array}$ \\
\hline$\lambda \max (\mathrm{nm})$ & 395 & 395 \\
\hline Linear concentration range $\left(\mu \mathrm{g} \mathrm{mL}^{-1}\right)$ & $0.5-22.5$ & $0.5-22.5$ \\
\hline Molar absorptivity $\left(\mathrm{L} \mathrm{mol}^{-1} \mathrm{~cm}^{-1}\right)$ & - & $0.22 \times 10^{4}$ \\
\hline Stoichiometric relationship, CPT:MBTH & - & $1: 1 \quad 1: 2$ \\
\hline Detection limit $\left(\mu \mathrm{g} \mathrm{mL}^{-1}\right)$ & 0.11 & 0.19 \\
\hline Quantification limit $\left(\mu \mathrm{g} \mathrm{mL}^{-1}\right)$ & 0.5 & 0.5 \\
\hline $\begin{array}{l}\text { Sandell's sensitivity }\left(\mu \mathrm{g} \mathrm{cm}^{-2} \text { per }\right. \\
0.002 \text { absorbance unit) }\end{array}$ & - & 0.0196 \\
\hline Regression equation $^{\text {a }}$ & $\begin{array}{c}\log v=\log \frac{\Delta A}{\Delta t}=\log \mathrm{k}^{\prime}+\mathrm{n} \log \mathrm{C} \\
\log v=0.9788+0.9336 \log \\
{[\mathrm{CPT}]} \\
\mathrm{k}^{\prime}=9.52 \mathrm{~s}^{-1}\end{array}$ & $\begin{array}{c}\mathrm{A}=0.0752 \mathrm{C}+ \\
0.1952 \\
\mathrm{~m}=0.0752 \\
\mathrm{~b}=0.1952\end{array}$ \\
\hline Correlation coefficient, $\mathrm{r}$ & 0.9994 & 0.9971 \\
\hline
\end{tabular}

${ }^{a} \mathrm{~A}=\mathrm{mC}+\mathrm{b}$, where $\mathrm{A}$ is the absorbance and $\mathrm{C}$ is the concentration in $\mu \mathrm{g} \mathrm{mL}{ }^{-1}$.

$\log \mathrm{v}=\log \frac{\Delta \mathrm{A}}{\Delta \mathrm{t}}=\log \mathrm{k}^{\prime}+\mathrm{n} \log \mathrm{C}$, where $\frac{\Delta \mathrm{A}}{\Delta \mathrm{t}}$ reaction rate, $\mathrm{k}^{\prime}$ is the pseudo order rate constant, $\mathrm{c}$ is the concentration of the CPT $\left(\mathrm{mol} \mathrm{L}^{-1}\right)$ and $\mathrm{n}$ is the order of the reaction.

Comparison among the previous kinetic spectrophotometric methods for the determination of captopril are shown in Table 3. As it is seen in this table, some of the reported procedures are more sensitive but have drawbacks such as having a narrow linear range [11-13], involving heating [11], and some methods are not simple and required expensive or sophisticated instruments [10].

Table 3. Comparison among kinetic spectrophotometric methods for the determination of captopril.

\begin{tabular}{|c|c|c|c|c|}
\hline Reagents & $\begin{array}{c}\lambda_{\max }, \\
\mathrm{nm}\end{array}$ & $\begin{array}{l}\text { Linear range } \\
\left(\mu \mathrm{g} \mathrm{mL}^{-1}\right)\end{array}$ & $\begin{array}{c}\text { Detection } \\
\text { Limits } \\
\left(\mu \mathrm{g} \mathrm{mL}^{-1}\right)\end{array}$ & Reference \\
\hline iodate & 350 & $10-60$ & - & [10] \\
\hline Sodium azide + iodine & 348 & $0.1-1.5$ & 0.02 & [11] \\
\hline $\begin{array}{c}\text { bromate-bromide }+ \\
\text { Fluorescein natrium }(\mathrm{FL})\end{array}$ & 436 & $0.2-4.50$ & 0.06 & {$[12]$} \\
\hline $\begin{array}{l}\mathrm{FeCl}_{3}+\text { potassium } \\
\text { ferricyanide }\end{array}$ & 730 & $1.0-11.0$ & 0.04 & {$[13]$} \\
\hline $\mathrm{FeCl}_{3}+(\mathrm{MBTH})$ & 395 & $0.5-22.5$ & 0.11 & Present work \\
\hline
\end{tabular}




\subsubsection{Stoichiometric relationship}

The composition of colored oxidative coupling product was determined by Job's method of continuous variation and mole-ratio method [33], for fixed time (8 $\mathrm{min})$ method. It is apparent from the data that a molar ratio of $1: 1$ and 1:2 CPT to MBTH (Fig. 7and 8 ).

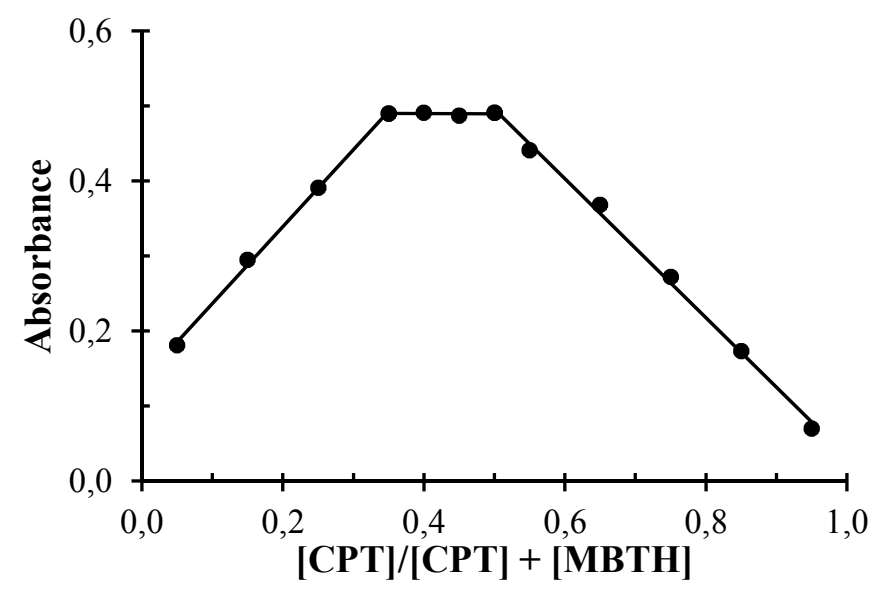

Figure 7. Job's method of continuous variations; $[\mathrm{CPT}]+[\mathrm{MBTH}]=10 \times 10^{-5} \mathrm{M}$.

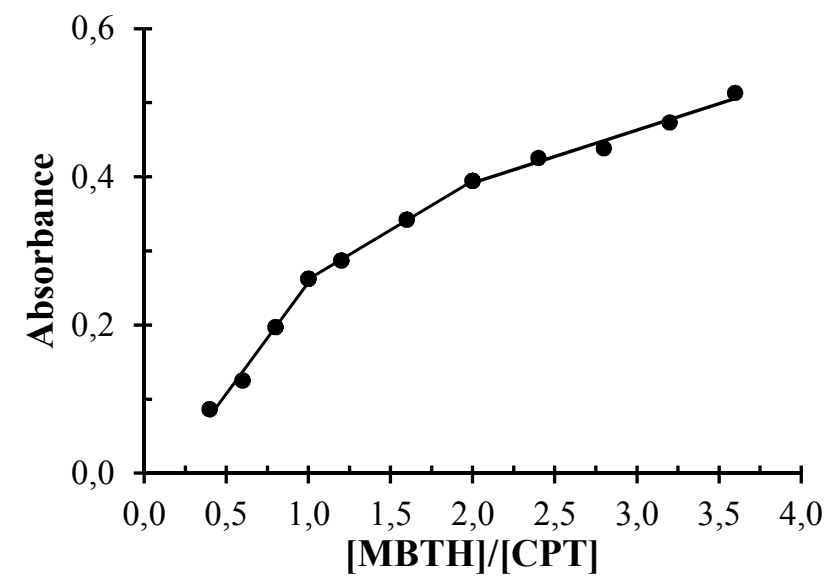

Figure 8. Mole-ratio method; $[\mathrm{CPT}]=2.5 \times 10^{-5} \mathrm{M},[\mathrm{MBTH}]=1.0 \times 10^{-5}-1.0 \times 10^{-4} \mathrm{M}$.

\subsubsection{Accuracy and precision}

The accuracy and precision of the proposed methods were carried out by five determinations at three different concentrations. Percentage relative standard deviation (RSD \%) as precision and percentage recovery as accuracy of the suggested methods were calculated and showed in Table 4 . The values of relative standard deviations for different concentrations of CPT determined from the calibration curves. These results of accuracy and precision show that the proposed methods have good repeatability and reproducibility.

The proposed methods were found to be selective for the estimation of CPT in the presence of various tablet excipients. For this purpose, a powder blend using typical tablet excipients was prepared along with the drug and then analyzed. The recoveries were not affected by the excipients and the excipients blend did not show any absorption in the range of analysis. 
Table 4. Accuracy and precision for the determination of CPT in bulk powder by the proposed rate data and fixed time methods.

\begin{tabular}{|c|c|c|c|c|c|c|}
\hline \multirow{2}{*}{ Method } & \multicolumn{3}{|c|}{ CPT, $\boldsymbol{\mu g ~ m L}^{-\mathbf{1}}$} & \multirow{2}{*}{ RSD \% } & \multirow{2}{*}{ Confidence limit } & \multirow{2}{*}{ Recovery \% } \\
\cline { 2 - 7 } & Taken & Found $^{\mathbf{a}}$ & SD & & & \\
\hline \multirow{3}{*}{ Rate data } & 5.00 & 4.97 & 0.13 & 2.62 & $4.97 \pm 0.16$ & 99.40 \\
\cline { 2 - 7 } & 7.50 & 7.52 & 0.10 & 1.33 & $7.52 \pm 0.15$ & 100.27 \\
\cline { 2 - 7 } & 15.00 & 14.83 & 0.15 & 1.01 & $14.83 \pm 0.19$ & 98.87 \\
\hline \multirow{3}{*}{ Fixed time } & 5.00 & 5.02 & 0.05 & 1.00 & $5.02 \pm 0.06$ & 100.40 \\
\cline { 2 - 7 } & 7.50 & 7.51 & 0.03 & 0.40 & $7.51 \pm 0.04$ & 100.13 \\
\cline { 2 - 7 } & 15.00 & 14.99 & 0.02 & 0.13 & $14.99 \pm 0.02$ & 99.93 \\
\hline
\end{tabular}

${ }^{\mathrm{a}}$ Five independent analyses.

\subsection{Application to the pharmaceutical dosage forms}

The rate data and fixed time methods of the proposed kinetic spectrophotometric method for determining CPT have been performed on commercial pharmaceutical tablets. The concentration of $\mathrm{CPT}$ was computed from its corresponding regression equations. The results of the proposed methods (rate data or fixed time) were statistically compared with those of the reported method [34], in respect to the accuracy and precision. The mean recovery values of the claimed amounts were between 99.39 and $101.64 \%$ (Table 5).

The results of t-and F-tests indicated no significant differences between both the proposed and the reported methods at $95 \%$ confidence level. This indicated similar precision and accuracy in the analysis of CPT in tablets.

Table 5. Determination of CPT in different pharmaceutical formulations by the proposed and official methods.

\begin{tabular}{|c|c|c|c|}
\hline \multirow{3}{*}{ Formulation } & \multirow{2}{*}{\multicolumn{2}{|c|}{$\begin{array}{c}\% \text { Found }^{\mathrm{a}} \pm \mathrm{SD} \\
\text { Proposed methods }\end{array}$}} & \multirow{3}{*}{ Official method [34] } \\
\hline & & & \\
\hline & rate data & Fixed time & \\
\hline \multirow{3}{*}{$\begin{array}{l}\text { Captomed } \\
(25 \mathrm{mg} / \mathrm{tab})\end{array}$} & $99.39 \pm 0.17$ & $101.54 \pm 0.24$ & \multirow{3}{*}{$\begin{array}{c}99.60 \pm 0.10 \\
t=2.23\end{array}$} \\
\hline & $\mathrm{t}=0.92$ & $\mathrm{t}=1.39$ & \\
\hline & $\mathrm{F}=2.89$ & $\mathrm{~F}=5.76$ & \\
\hline \multirow{3}{*}{$\begin{array}{c}\text { Captomed } \\
(50 \mathrm{mg} / \mathrm{tab})\end{array}$} & $99.60 \pm 0.19$ & $100.95 \pm 0.18$ & \multirow{3}{*}{$\begin{array}{c}100.80 \pm 0.30 \\
t=1.49\end{array}$} \\
\hline & $\mathrm{t}=0.70$ & $\mathrm{t}=1.74$ & \\
\hline & $\mathrm{F}=2.49$ & $\mathrm{~F}=2.78$ & \\
\hline \multirow{3}{*}{$\begin{array}{c}\text { Capoten } \\
(25 \mathrm{mg} / \mathrm{tab})\end{array}$} & $99.71 \pm 0.37$ & $101.43 \pm 0.22$ & \multirow{3}{*}{$\begin{array}{c}98.40 \pm 0.35 \\
t=2.55\end{array}$} \\
\hline & $\mathrm{t}=0.18$ & $\mathrm{t}=1.42$ & \\
\hline & $\mathrm{F}=3.42$ & $\mathrm{~F}=2.50$ & \\
\hline \multirow{3}{*}{$\begin{array}{c}\text { Capoten } \\
\text { (50 mg/tab) }\end{array}$} & $99.98 \pm 0.37$ & $101.64 \pm 0.38$ & \multirow{3}{*}{$\begin{array}{c}99.20 \pm 0.20 \\
t=2.23\end{array}$} \\
\hline & $\mathrm{t}=0.12$ & $\mathrm{t}=1.41$ & \\
\hline & $\mathrm{F}=3.42$ & $\mathrm{~F}=3.61$ & \\
\hline
\end{tabular}

${ }^{\mathrm{a}}$ Five independent analyses. At 95\% confidence level t-value is 2.776 and F-value is 6.26 .

\section{Conclusion}

The developed kinetic spectrophotometric methods for the determination of CPT are simple, accurate and precise and hence can be used for the routine analysis of CPT in pharmaceutical formulations. The proposed methods are sensitive enough to enable determination of lower amounts of the drug, and compared with the previously reported methods in terms of accuracy and precision, which suggested non interference of formulations excipients in the estimation. These advantages encourage the application of the proposed methods in routine analysis of CPT in quality control laboratories as alternatives for the existing methods. 


\section{References}

[1] L. Brunton et al., The Pharmacological Basis of Therapeutics, 10th ed, McGraw-Hill, 2001.

[2] K. Parfitt, W. Martindale, The Complete Drug Reference, The Pharmaceutical Press, London. 720 (1999) 836.

[3] D.W. Cushman et al., Design of potent competitive inhibitors of angiotensin-converting enzyme. Carboxyalkanoyl and mercaptoalkanoyl amino acids, Biochemistry. 16 (1977) 54845491.

[4] P.R.S. Ribeiro, L. Pezza, H.R. Pezza, A simple spectrophotometric method for the determination of captopril in pharmaceutical preparations using ammonium molybdate, Eclet. Quim. 35 (2010) 79-88.

[5] P.D. Tzanavaras et al., Reversed flow-injection manifold for the spectrophotometric determination of captopril based on its inhibitory effect on the $\operatorname{Co}$ (II) - 2,2'-dipyridyl-2pyridylhydrazone complex formation, Talanta. 57 (2002) 575-581.

[6] A.M. El-Didamony, E.A.H. Erfan, Spectrochim, Utilization of oxidation reactions for the spectrophotometric determination of captopril using brominating agents, Spectrochimica Acta Part A: Molecular and Biomolecular Spectroscopy. 75(3) (2010) 1138-1145.

[7] N.E. Enany, F. Bela, M. Rizk, Novel Spectrophotometric method for the assay of captopril in dosage forms using 2,6-Dichloroquinone-4-Chlorimide, Int. J. Biomed Sci. 4 (2008) 146-154.

[8] M. Skowron, W. Ciesielski, Spectrophotometric determination of methimazole, Dpenicillamine, captopril, and disulfiram in pure form and drug formulations, J. Anal. Chem. 66 (2011) 714.

[9] I. Panderi, M. Parissi-Poulou, Determination of captopril and captopril-hydrochlorothiazide combination in tablets by derivative UV spectrophotometry, Int. J. Pharm. 86(2-3) (1992) 99106.

[10] J.A.V. Prior, J.L.M. Santos, J.L.F.C. Lima, Exploiting kinetic spectrophotometric determination of captopril, an angiotensin-converting enzyme inhibitor, in a multi-pumping flow system, Anal. Chim. Acta. 600 (2007) 183-187.

[11] Y. El-Shabrawy, N. El-Enany, K. Salem, Sensitive kinetic spectrophotometric determination of captopril and ethamsylate in pharmaceutical preparations and biological fluids, Il Farmaco. 59(10) (2004) 803-808.

[12] Z. Moldovan, A Spectrophotometric method for captopril determination by using fluorescein natrium-bromine system, Rev. Roum. Chim. 57 (2012) 721-727.

[13] N. Rahman et al., A sensitive kinetic spectrophotometric method for the determination of captopril in bulk and dosage forms, Acta. Pharm. 56 (2006) 347-357.

[14] M. Jain, S.N. Shrivastava, A stability indicating assay method for captopril tablets by high performance liquid chromatography for stability studies, Anal Chem. 3 (2006) 78-83.

[15] D. Meiju, Determination of captopril in human plasma by liquid chromatography/tandem mass spectrometry, Anal Lett. 40 (2007) 3245-3255.

[16] R.J. Kok et al., Bioanalysis of captopril: two sensitive high-performance liquid chromatographic methods with pre-or postcolumn fluorescent labeling, J. Chrom. B. Biomed. Sci. Appl. 693(1) (1997) 181-189.

[17] J.A. Squella et al., Voltammetric behaviour of captopril in pharmaceutical forms, Bol. Soc. Chil. Quim. 37 (1992) 259. 
[18] P. Passamont, V. Bartcci, F. Pucciarelli, Determination of Captropril using adsorptive cathodic differential pulse stripping voltammetry with the HMDE, Journal of electroanalytical chemistry and interfacial electrochemistry. 230(1) (1987) 99-108.

[19] G.K. Ziyatdinova, G.K. Budnikov, V.I. Pogorel'tsev, Determination of captopril in pharmaceutical forms by stripping voltammetry, J. Anal. Chem. 61 (2006) 798-800.

[20] S.M. Al-Ghannam, A.M. El-Brashy, B.S. Al-Farhan, Fluorimetric determination of some thiol compounds in their dosage forms, Il Farmaco. 57 (2002) 625-629.

[21] M.A. El Reis, F.M. Abou Attia, I.M.M. Kenawy, Indirect determination of captopril by AAS, J. Pharm. Biomed. Anal. 23 (2000) 249-254.

[22] A.M. Pimenta, A.N. Araújo, M.C.B.S.M. Montenegro, Sequential injection analysis of captopril based on colorimetric and potentiometric detection, Anal. Chim. Acta. 438 (2001) 31-38.

[23] Jr. E. Schmidt, W.R. Melchert, F.R.P. Rocha, Flow-injection iodimetric determination of captopril in pharmaceutical preparations, J. Braz. Chem. Soc. 20 (2009) 236-242.

[24] B. Li, Z. Zhang, M. Wu, Flow-injection chemiluminescence determination of captopril using on-line electrogenerated silver (II) as the oxidant, Microchemical Journal. 70(2) (2001) 85-91.

[25] P.D. Tzanavaras, Automated Determination of Captopril by Flow and Sequential Injection Analysis: A Review, Anal. Lett. 44 (2011) 560-576.

[26] M. A. Khalilzadeh et al., Determination of captopril in patient human urine using ferrocenemonocarboxylic acid modified carbon nanotubes paste electrode, Chin. Chem. Lett. 21 (2010) 1467-1470.

[27] S.R. Crouch et al., Kinetic determinations and some kinetic aspects of analytical chemistry, Anal. Chem. 70 (1998) 53-106.

[28] A. Espinosa-Mansilla et al., Kinetic determination of ansamicins in pharmaceutical formulations, Anal. Chim. Acta. 376 (1998) 365-375.

[29] R.A. Bartsch, S. Hunig, H. Quast, Mechanism of oxidation of 3-methyl-2-benzothiazolinone hydrazone by potassium ferricyanide in aqueous methanol, J. Am. Chem. Soc. 92 (1970) 6007-6011.

[30] A.R. Kartritzky, C.W. Rees, Comprehensive Heterocyclic Chemistry, Pergamon Press, Oxford. 7 (1984) 527.

[31] M. Kopanica et al., Kinetic Methods in Chemical Analysis, Eds., Elsevier, Amsterdam, The Netherlands, 1983.

[32] D.P. Bendito, M. Silva, Kinetic Methods in Analytical Chemistry, chapter 11, John Wiley \& Sons, New York, USA, 1988.

[33] J. Rose, Advanced Physico-chemical Experiments: A Textbook of Pract. Phys. Chemistry and Calculations, Pittman, London, 1964.

[34] USP - The United States Pharmacopeia: The National Formulary. 25th ed. Rockville: The United States Pharmacopeial Convention - Twinbrook Parkway, 2007. 